\title{
A Study on the Impact of South Korea's Official Developmental Assistance Policy toward Vietnam
}

\author{
Seungho Jeong \\ Graduate School of Global Studies, Doshisha University, Kyoto, Japan \\ Email: ewp1103@mail3.doshisha.ac.jp
}

How to cite this paper: Jeong, S. (2018) A Study on the Impact of South Korea's Official Developmental Assistance Policy toward Vietnam. Modern Economy, 9, 1439-1451. https://doi.org/10.4236/me.2018.98091

Received: July 1, 2018

Accepted: August 21, 2018

Published: August 24, 2018

Copyright $\odot 2018$ by author and Scientific Research Publishing Inc. This work is licensed under the Creative Commons Attribution International License (CC BY 4.0).

http://creativecommons.org/licenses/by/4.0/

\section{(c) (i) Open Access}

\begin{abstract}
The purpose of this research paper is to study and analyze the Official Development Assistance (ODA) policy of South Korea toward Vietnam. The research methodology used was qualitative and relied on processed information from secondary sources. It is noted that South Korea has been a major foreign aid partner of Vietnam since it became a donor member of the Development Assistance Committee (DAC). Currently, South Korea preferentially gives Vietnam the largest share of its donor funds in the form of concessional loans and grants. Also found in this investigation is that the main determinant of this sizable ODA is in the form of commercial opportunities available in the recipient country and the rich diplomatic relations shared by the two countries. South Korea has realized commercial benefits such as an expanded market for exports, employment opportunities for its citizens, and foreign direct investment (FDI) chances in Vietnam as a result of this ODA volume. On the other hand, Vietnam has used money received to immensely transform its economy. In conclusion, the ODA policy of South Korea toward Vietnam has been found to be largely beneficial for both countries.
\end{abstract}

\section{Keywords}

Official Development Assistance, South Korea, Vietnam, Foreign Direct Investment, South Korea-Vietnam Relations

\section{Introduction}

South Korea is a country that has itself come from ruins of Korean War to prosperity. It is a participant in the Organization for Economic Cooperation and Development (OECD). It was initially a donor-recipient country but wisely used 
its aid to invest heavily in economic development. South Korea showed the world how speedy economic growth is achievable. Today, South Korea offers mentorship and financial assistance to other developing countries like Vietnam. South Korea has shown great interest in supporting Vietnam to achieve its developmental goals of the past.

In fact, many analysts and observers have been surprised by South Korea's preferential treatment of Vietnam in terms of ODA. The true basis of South Korea's principal foreign policy in allocating this resource has raised many questions. The purpose of this research paper is to investigate the real meaning of ODA and establish what South Korea has done in Vietnam. The research will also focus on the merits and demerits of the approach taken by South Korea by analyzing the results of the ODA in Vietnam. The paper also contains recommendations on the best way South Korea can carry out its future ODA to Vietnam and other nations.

\section{Literature Review}

The concept of foreign aid has strongly emerged to become one of the main forces behind the economic growth of countries, in both developing and developed ones. As a result of the high importance of this field, we have seen an increased interest among researchers and economic scholars to conduct studies which analyze the concept of ODA. South Korea's ODA in particular has been a popular subject of research because of its unusually large size; researchers are also attracted by the country's open preference for Vietnam in its ODA policy. It is clear from the literature reviewed that foreign aid began to be used by countries interested in assisting others to grow economically, or simply achieve economic reconstruction, immediately after the Second World War. It is also through foreign aid that peace and poverty eradication is achieved in countries around the world.

The OECD defines ODA as the financial resource flow given by governments of the donor nations towards other countries, as well as multi-national organizations, listed as recipients by OECD DAC. The main goal for the ODA is the attainment of economic and social development [1]. It is important to note that the amount of financial aid given out by governments has been increasing steadily throughout the world; researchers have established that the South Korean monetary aid flow follows the global financial assistance trend. ODA is seen as the main tool for helping the world to eradicate poverty before 2030 .

Aid is not just given out haphazardly but follows clear and objective models including the donor and recipient countries' foreign policies. Unsurprisingly, countries give out foreign aid based on their own vested interests and expected benefits. Furthermore, they examine the effectiveness of a planned donation before implementing it. Notably, recipient nations also check the aid allocation policies of donor countries before starting to study the potential effectiveness of the aid. In the absence of aid allocation policy analysis, however, it is difficult for 
the recipient country to understand the sectors and goals in which donor nations are interested as they implement their ODA. Therefore, in real scenarios, political and diplomatic relations alone cannot drive financial aid. In other words, economic aid is not just given for the purpose of political and diplomatic expediency.

The common model used by many donor nations has contributed towards the development of other less developed countries based on their Sustainable Development Goals (SDGs) [2]. Every nation's allocation of ODA is aimed at reaching various regions. Different purposes work to inform the ODA allocation. Considering the fact that South Korea is a relatively new member of the DAC, having joined in 2010, it is expected that its ODA policies are dedicated to and driven by the goals of poverty eradication as well as economic growth in its chosen recipient nations. Truly, South Korea is a nation that has itself experienced growth stimulated by donor finances. South Korea used to depend on foreign aid in the 20th century. For its case as a recipient of ODA, donors were driven by geopolitical strategies. Its main donor was the United States of America. Current literature reveals that donor funds enabled South Korea to reconstruct its devastated economy and stabilize it [3]. An example is when most basic commodities and foreign investments were funded by foreign aid grants brought in by the United Nations Korea Reconstruction Agency (UNKRA) and the United States' bilateral assistance program. At that time, foreign aid was used by South Korea to import necessary foodstuffs, capital goods, and industrial raw materials. In fact, 75\% of the investments made by South Korea between 1953 and 1960 were funded by foreign assistance money [3]. This country was just removed from the DAC list of aid recipients in the year 2000 and is currently the 24th member of OECD [3]. Considering the historical timeline, it is evident that foreign aid started to be used by governments even before the 1940s. In the early times of development assistance use, there was the aid from British and French diplomatic realism. However, the modern model of foreign aid originated in the late 1940s after the Second World War [4], with the provision of Marshall Aid by the United States in support of economic reconstruction within the European nations. Most of the recipient nations' economies had been badly destroyed by the war [5], with the provision of Marshall Aid by the United States in support of economic reconstruction within the European nations. Most of the recipient nations' economies had been badly destroyed by the war.

Since then, foreign aid has been described differently by scholars depending on the way it is implemented by the countries involved. It basically entails giving assistance to another country that is in need. This assistance may be in the form of money, food, or goods. Additionally, the aid given out may be in the form of human technical skills.

Current literature is abounding with explanations of the determinants of foreign aid. From the body of literature which covers the Marshall Aid plan, it can be learned that foreign aid is donor assistance-driven. Scholars have delved into 
the issue of establishing the reasons which motivate countries to give ODA. What complicated previous studies examining the forces behind foreign aid is the fact that countries have varied reasons and aims for giving developmental assistance to needy nations. Moreover, the donor nations realize varied results from this action. It is worth noting that the framework for developmental assistance in the world has been changed dramatically over recent years. Alterations in this model are normally caused by the emerging global developmental issues faced by countries.

There has been huge interest among researchers to understand what motivations shape foreign assistance models, policies, and decisions. Eight major classes of motivations that inform ODA decisions have been established [6]: The first is about helping address emergency needs of recipient nations; the second is about assisting developing countries to attain economic growth and reduction of the poverty level; the next is about showing solidarity and cooperation with other nations; the fourth is that countries are motivated by their vested national political and strategic interests [7]; the next is the need to foster donor country commercial goals; the sixth is based on the historical ties established between nations; the seventh is interest in promoting the production of global public goods; lastly, many countries are motivated by the need to address human rights at risk of violation in other nations.

Empirical studies reviewed in this paper have established the above eight motivations as main factors that influence the decision to assist other countries. The identified classes of motivations are premised on the theories of idealism, neo-realism, and realism. They are now the benchmarks used by most countries to inform their ODA policies. It is vital to analyze the information given in literature about each motivation before focusing on the postulations of scholars regarding the determinants of South Korea's ODA policy.

\section{National Politics and Strategy Interests}

\subsection{Political Interests}

According to the theory of realism, the foreign assistance policies of countries are aligned to the national strategic and political interests such as internal security and external defense [8]. Realists believe that there are self-interests which push a country into assisting another one to develop. If this theory is considered, then it implies foreign aid is an investment meant to achieve abstract returns, including peace and security. A country is not simply convinced to give out money for assistance because of the problems and issues experienced by its ally.

This idea has been practically observed in a number of foreign aid decisions by governments. For instance, France and the United States usually based their foreign aid decisions on self-interests of politics and national strategies. The United States aligns its aid to Middle East countries with its national interests, especially defense from external threats. A number of other donors also use this factor in determining their ODA allocations. Countries that are not poor may 
receive aid from other nations because of their strategic positions in terms of the national interests of the donor [9].

There are many times when the United States has come out to offer economic and military assistance to Israel, despite this country not being poor at all [10]. This motive is largely applied by nations considered as powers, as well as those rising to attain this status.

\subsection{Economic Interests}

Perhaps the primary motive for countries' foreign aid decisions is their economic interests. Foreign aid has emerged as the biggest seduction tool used by able countries in achieving their economic interests in the recipient nations. This view is held by neo-realist analysts, who believe that commercial reasons shape the ODA allocations seen in the world. Notably, most developing countries have economic opportunities that remain untapped. A nation may be lacking in terms of the requisite capital and human resource capacities for exploitation of such opportunities. Developed countries usually identify these opportunities and analyze their value before deciding to give foreign assistance. In this case, the aid given is meant to allow the donor access these identified economic opportunities. Economic opportunities in developing countries may include large consumer markets, natural resources, and other general business opportunities [11]. For example, the emerging powers in Asia, such as China and Japan, are motivated by their individual economic interests when aiding needy nations in Africa. Additionally, the ODA allocation of Japan toward China is highly related to its foreign direct investments and export volumes in the same country. Japan is also said to always recycle its trade surplus with the United States by offering foreign assistance to Latin America nations that back the security and economic plans of the United States.

The common observation by scholars is that there is a strong correlation between ODA allocations of donor countries and the trade volumes they have with their specific recipient countries. It is always an evident fact that major aid recipients are also the big trading partners of donor countries. In fact, this factor always plays out in the drafting of terms and conditions for the assistance given to recipients. In most cases, donor countries always demand that the materials as well as human and capital resources to be used in the infrastructural projects of recipients be acquired from the aiding nation. It is the reason donor countries give financial assistance to specific developmental projects in other countries. This concept has been researched and seen in many aid programs of countries such as China and Japan. China always gives financial aid to infrastructural projects in African countries. Part of the requirements given by the country is the acquisition of raw materials and human resources from the country. Most of the roads and big buildings constructed in Africa are the work of the Chinese, with raw materials purchased from the same nation.

The reality, as suggested by scholars in current literature on this topic, is that 
countries are in the business of giving foreign aid to recipients according to the mutual benefits involved. No government gives out foreign aid to a nation just for the sake of pure generosity [12]. Every government giving monetary aid to other countries is assumed to be rational in its decision making. Governments are rational in the sense that they take out money collected from their individual citizens in form of taxes to aid foreign countries based on an evaluation of the inherent economic value return. A recipient that promises zero economic value return to the donor nation cannot get the assistance.

\subsection{Historical Connections}

The other motivation for foreign aid is the issue of historical connections between countries. Historical connections may be in the form of neighborhood; perhaps the countries have faced similar problems or colonial relations in the past. Specifically, European countries like Germany and Britain give assistance to their former colonies. The foreign assistance given out by Britain to many countries in Africa is based on their colonial ties. For example, there is a political body known as Commonwealth which is composed of Britain and its former colonies in Africa. The issue of geographical proximity is the main motive for ODA from Japan to countries in Asia. Studies have established that fellow Asian nations have always taken the largest share of free Japanese aid because of neighborhood ties. Believably, the foreign aid may be based on geopolitics; that is, a nation may give foreign aid to its neighbors with the intention of achieving certain geopolitical goals.

\subsection{Humanitarian Motives}

Lastly, another major motivation for offering foreign aid is the need for salvaging dwindling human rights. There are situations where donor countries are forced to act generously with a view to saving fellow human beings. For instance, the case of countless deaths due to the recent earthquake in Haiti attracted major monetary and material contributions from various governments. Most of the contributions were premised on the need to ensure the people of Haiti realized basic human rights, such as access to food.

Idealists agree that foreign assistance has to be accorded to people who are helpless. The idealism theory regards the human race as an equal one, where every person is entitled to preserving and enjoying life. Therefore, where some people fail to realize the right of enjoying their lives because of stressful conditions, it is imperative for nations to step in and help such individuals get better living standards. It is the reason many scholars now push for the recognition of poverty as a humanitarian problem in the world. Many policymakers who play at the global level are pushing for joint international efforts meant to eradicate poverty since it is a threat to human rights. Some countries and donor institutions have agreed on this suggestion and treat poverty in various parts of the world as a humanitarian issue that requires foreign assistance to fight it effec- 
tively. Many nations across the world are bound by the international human rights laws developed by the United Nations Organization (UNO). It is always a voluntary act and decision for a nation to put itself under the rule of the international human rights laws. The international human rights are widely proclaimed as universal values of our world society. Donor countries feel obliged to take part in funding the course of ensuring that every human being realizes the basic rights in life. It is a major motivation for most of the foreign aid given to nations stricken by big disasters like hurricanes and tsunamis.

\section{Vietnam's Socio-Economic Situation}

Vietnam is located in Southeast Asia. Currently, Vietnam has a population of about 96 million. (July 2017 est). Its land space is 310,070 square kilometers. Also, GDP per capita (PPP) is 6900 USD (2017 est) [13]. It is endowed with rich natural resources as well as a warm climate, which attracted different colonizers in the past. China, France colonized it. When it became independent in 1954 after defeating its French colonizers, it was divided into North and South, with each territory being ruled by a different regime. Later on, the two territories reunited to form one country. This reunification in the year 1975 was not a source of pure happiness, because it came with an economic crisis that affected the country [14]. The socialist regime and the single Communist Party (Communist Party of Vietnam) have for a long time ruled the country. Vietnam suffered economically during the late 1970s and early 1980s. There was lack of foreign investment and the technology gap between Vietnam and neighboring countries [15]. At the height of the economic crisis that was occasioned by the stoppage of foreign aid by the Soviet Union as well as the Communist Bloc, the government of Vietnam decided to start a rigorous political and economic reform agenda known as Doi Moi [16]. Under the Doi Moi plan, the country managed to transform its centrally-planned economy to a more socialist-oriented market economy. This development greatly changed the country and made it more attractive to foreign assistance.

The development cooperation timeline of Vietnam and other nations is normally divided into two major periods. Before Doi Moi in the year 1986, Vietnam greatly depended on external support for its developmental record from the Soviet Union and China [17]. The biggest financier of Vietnam had been the Soviet Union. The greatest share of external trade in Vietnam was also reported to be with the Soviet Union, until it officially ended its major assistance to Vietnam in the mid-1980s [18]. The main reason for this abrupt interruption of ODA from the Soviet Union to Vietnam was the fall of the socialist regime.

After this development, the Vietnamese government realized that it was an important time for the nation to reevaluate, reengineer, reform, and revise its economic policies. It ratified radical socio-economic policies meant to ensure that the country realized significant development. The government of Vietnam realized the meaningful development of the economy lay in exploiting the ad- 
vantages, which are normally inherent in the connection between national security and economic resources available. It needed to take advantage of the high internal security and exploitation of available economic resources to better control the foreign cooperation relations and achieve great socio-economic development.

Vietnam used its lessons from the cons experienced as a result of the dependence on the Soviet Union to start reforming its socio-economic and political profile. It began to cultivate a good bilateral relationship with the United States in 1993. Thereafter, the country started to get more external cooperation deals with other countries loyal to the United States. From that time, Vietnam has been receiving a huge inflow of external resources such as FDI and ODA from various nations. It is currently among the most popular recipients of ODA and FDI. The difference now is that the ODA donors are attracted to the country because of the internal commercial and strategic opportunities it offers them. Vietnam is now an attractive nation to invest, as observed from the literature reviewed.

\section{The Effectiveness of Aid}

The question of aid effectiveness is a fundamental one that scholars now focus on in their studies. The effectiveness of foreign aid refers to the extent to which aid has been put to good implementation and resulted in desired results, as originally envisioned by both the donor and recipient. In the contemporary world where government coffers have been taken over by corrupt cartels that borrow or give out monetary aid as a conduit for plundering and swindling tax revenue, the effectiveness of assistance is a concept worth discussing especially when talking about South Korea's ODA towards Vietnam.

It is vital to note again that any foreign aid is normally given out for the purpose of promoting economic development and alleviating poverty. In some instances, foreign aid is given for the specific purpose of assisting people to realize their human rights. However, when mismanaged, the aid may fail to achieve these goals. In some quarters, foreign aid has been criticized because of its negative impact on recipient nations. The issue of aid effectiveness has, thus, become highly controversial in the recent past. The criticism leveled against foreign aid volumes given by donor countries is that it has led to grown government bureaucracies, bad governance, and high corruption within governments where a few elites benefit as the majority poor become poorer since they have to shoulder the burden of repaying the concessional loans given through tax.

Nevertheless, foreign aid has also had its immense benefits in the past. Many countries that were initially poor have been able to realize great developmental strides through the use of foreign aid. One real example is South Korea, which used to depend on ODA from the United States and Japan. It is now stable and assists other nations. In essence, the question of ODA effectiveness is of great concern to analysts and scholars who question the way money is used and the 
resultant pros as well as cons of this assistance. Research done by various scholars shows that foreign aid is only effective when given to nations with sound fiscal, monetary, and trade policies. In essence, the effectiveness of foreign aid depends on the structures aid by the recipient nation and its policies. The management of the same aid is also necessary for its effectiveness and realization of the desired results.

\section{The Determinants of South Korean ODA}

South Korea has attracted the attention of scholars because it is an emerging donor for development in other developing countries and also because of its special profile when it comes to ODA. It is a country that was once a listed recipient on DAC, but later became an official donor recognized by the same institution. Numerous studies have been carried out to establish the major motivations for South Korea's ODA actions. There has been controversy over findings regarding the impact of South Korean ODA on recipient nations. Many feel the assistance given by South Korea usually does not create significant economic impact in the recipient nation. However, economic interests have been established as the major motivation for South Korea's ODA decisions. South Korea gives ODA to nations that present attractive FDI and trade opportunities. Therefore, the aid given by South Korea is always statistically effective in fostering international trade and FDI with the recipient nation.

\subsection{Research Methodology}

The purpose of this research is to analyze the ODA policy of South Korea in Vietnam and investigate the results realized. The study involved checking impeccable sources of information related to the recent ODA policies of South Korea. It also investigated articles that report interesting findings on the relationship between South Korea and Vietnam. The impact of the foreign aid given by South Korea to Vietnam was established through analysis of the economic status of the recipient nation as well as the commercial benefits realized by the donor country. Empirical analysis of processed information collected was carried out to make meaningful interpretations that could enable logical conclusions regarding South Korea's ODA policies.

\subsection{South Korea's ODA toward Vietnam}

The South Korean ODA system is normally managed by two main organizations, the Economic Development Cooperation Fund (EDCF) and the Korean International Cooperation Agency (KOICA) [19]. Importantly, these two organizations, both charged with the responsibility of controlling the ODA policies of South Korea, normally pursue different goals. Specifically, the EDCF pursues the goal of cooperating with the recipient countries in achieving economic development by advancing them concessional loans [19]. On the other hand, KOICA targets improvement of socio-economic stability in the recipient nations through 
mutual interactions involving giving out grants. It is established that the institutional framework of South Korea's ODA system is comprised of a coordinating body and supervisory and executive ministries and agencies. However, many unanswered questions still exist regarding the internal structure of the country's ODA system. One of the problems identified in the course of this investigation is the highly recognized issue of fragmentation. In a bid to address this issue, the Ministry of Strategy and Finance, together with that of Foreign Affairs, co-lead the government's inter-Agency EDCF Committee and the Inter-Agency Grants Committee. The KOICA-EDCF Senior Officers' Meeting is normally held regularly with the goal of building a regional network. Within the institutional framework of the country's ODA, it has been established that the coordinating body is in charge of deliberating and deciding the general ODA policies for greater policy coherence as well as the delivery of aid programs in a systematic manner. The ministries are in charge of supervising concessional loans and grants and write up mid-term ODA policy. KOICA and the Korea Eximbank are the implementers of the aid and concessional loans respectively [20].

The relationship between the two countries is not just premised on aid alone, but on other fronts like political and social cooperation. The two nations maintain diplomatic relations, which are based on strategic cooperation partnership. Strategic security interests have always played a major role in the decision of South Korea regarding ODA to Vietnam. Specifically, the military hostility that exists between South Korea and North Korea has always played out in the country's ODA decisions. Research also shows that Vietnam and South Korea have always sought to strengthen their diplomatic relations through the use of economic cooperation. This agenda has been pushed since the year 1992 when the two countries normalized their diplomatic relations, with the then Vo Van Kiet, the prime minister of Vietnam paying a state visit to South Korea with an economic mission on 13 May 1993. Vo Van Kiet also discussed economic cooperation with Koo Ja-kyung, the chairman of Lucky-Goldstar Corporation (currently LG Corporation) [21].

Also, South Korean President Lee Myung-bak and Vietnamese State President Nguyen Minh Triet agreed to upgrade their bilateral cooperation to a Strategic Cooperative Partnership on 21 October 2009 [22]. It is clear that ODA has laid a strong basis for the growth of diplomatic relations between South Korea and Vietnam. In essence, the level of relationship between Vietnam and South Korea is highly warm. It involves frequent visits by top leaders of the two countries to each other. Therefore, when talking about the pros of the ODA given by South Korea to Vietnam, it is vital to mention the issue of greater bilateral cooperation and strong diplomatic relations gained through this engagement.

The other pro noted during this investigation is the great economic benefit realized by both countries. South Korea has strategic commercial interests that make it beneficial to advance ODA to Vietnam. Firstly, the ODA given out by South Korea to Vietnam has helped earn the country an expanded market for its 
exports. South Korea exports different goods to Vietnam, which offers it one of its biggest markets. Additionally, South Korea is able to achieve FDI opportunities in Vietnam for its companies. Thus, the citizens of South Korea get employment while working in the various economic development projects of Vietnam. Part of the agreements reached when advancing concessional loans to Vietnam is that the recipient must employ human resources and purchase capital as well as raw materials from South Korea.

It also can be said that the ODA policy of South Korea has been effective in terms of helping Vietnam achieve meaningful economic transformation. Vietnam has transformed itself into a middle-income economy because of the foreign aid it receives from countries like South Korea.

However, there are also major cons of this ODA policy. Firstly, it has put much liability on the Vietnamese people, who now face huge debts in terms of concessional loans. Secondly, the ODA policy of South Korea has caused much government bureaucracy for Vietnam, where project programs have to go through many decision-making stages before implementation is done. As the donor, South Korea has to be involved in all the related projects of Vietnam. This condition slows down the speed at which the Vietnam government can implement its developmental projects. It ultimately slows down the rate of economic development in the country.

The main recommendation for South Korea is to reduce the inefficiency of its ODA program by eliminating its dual-aid delivery agency system. One agency should be selected between KOICA and EDCF so that effective controls can be implemented. The use of two agencies for similar or related work of delivering ODA is the cause of duplicity and inefficiency in the government's ODA programs. It is also important for the country to carry on with its strong funding for Vietnam since it earns more major benefits than demerits.

\section{Conclusion}

South Korea and Vietnam offer a classic example of what foreign aid can do for a country. It was established that South Korea prefers to disburse much of its financial assistance to Vietnam because of the political, bilateral, and commercial benefits this engagement earns. However, a number of challenges were noted, which included the government's duplicate agencies given the task of delivering foreign aid to Vietnam. South Korea should use one agency for this purpose so that efficiency and effectiveness can be achieved.

\section{Conflicts of Interest}

The authors declare no conflicts of interest regarding the publication of this paper.

\section{References}

[1] (2018). 
http://www.oecd.org/dac/stats/officialdevelopmentassistancedefinitionandcoverage. $\underline{\mathrm{htm}}$

[2] Kim, S. (2016) Trends and the Determinants of Korea's Official Development Aid (ODA) Allocation. Master's Thesis, Institute of Social Studies, The Hague, 2.

[3] Rudolph, A. (2017) The Concept of SDG-Sensitive Development Cooperation. Deutsches Institut für Entwicklungspolitik, Tulpenfeld, 1-3.

[4] Dollar, D. and Levin, V. (2006) The Increasing Selectivity of Foreign Aid, 1984-2003. World Development, 34, 2035.

[5] Alesina, A. and Weder, B. (2002) Do Corrupt Governments Receive Less Foreign Aid? American Economic Review, 92, 1127.

[6] Kim, E. and Oh, J. (2012) Determinants of Foreign Aid: The case of South Korea. Journal of East Asian Studies, 12, 255. https://doi.org/10.1017/S1598240800007852

[7] Sato, J., Shiga, H., Kobayashi, T. and Kondoh, H. (2011) "Emerging Donors" from a Recipient Perspective: An Institutional Analysis of Foreign Aid in Cambodia. World Development, 39, 2093. https://doi.org/10.1016/j.worlddev.2011.04.014

[8] Jain, P. (2014) National Interest and Japan's Foreign Aid Policy. Kokusai Mondai (International Affairs), No. 637, 2.

[9] Chun, H., Munyi, E.N. and Lee, H. (2010) South Korea as an Emerging Donor: Challenges and Changes on Its Entering OECD/DAC. Journal of International Development, 22, 789. https://doi.org/10.1002/jid.1723

[10] Tremblay-Boire, J. (2017) Addressing the Myths Surrounding U.S. Foreign Aid. PBS, April 10.

https://www.pbs.org/newshour/world/column-addressing-myths-surrounding-u-s-f oreign-aid

[11] Trinidad, D.D. (2007) Japan's ODA at the Crossroads: Disbursement Patterns of Japan's Development Assistance to Southeast Asia. Asian Perspective, 31, 96.

[12] Kim, E. and Oh, J. (2012) Determinants of Foreign Aid: The Case of South Korea. Journal of East Asian Studies, 12, 257. https://doi.org/10.1017/S1598240800007852

[13] (2018)

https://www.cia.gov/library/publications/the-world-factbook/geos/vm.html

[14] Pham, N.H. (2017) A Study on South Korean ODA to Vietnam. Master's Thesis, Graduate School of International Studies of Ewha Womans University, Seoul, 25.

[15] Mallon, R. and Van Arkadie, B. (2004) Viet Nam-A Transition Tiger? ANU Press, Canberra, 66. https://doi.org/10.26530/OAPEN_459765

[16] Mallon, R. and Van Arkadie, B. (2004) Viet Nam-A Transition Tiger? ANU Press, 75-77.

[17] Pham, N.H. (2017) A Study on South Korean ODA to Vietnam. Master's Thesis, Graduate School of International Studies of Ewha Womans University, 28.

[18] Pham, N.H. (2017) A Study on South Korean ODA to Vietnam. Master's Thesis, Graduate School of International Studies of Ewha Womans University, 30.

[19] Kim, S. (2016) Trends and the Determinants of Korea's Official Development Aid (ODA) Allocation. Master's Thesis, Institute of Social Studies, The Hague, 13.

[20] Neumayer, E. (2003) Pattern of Aid Giving. Routledge, London, 23.

[21] Kyunghyang Shinmun (1993) Gujagyeong Reokkigeumseonghoejang Betnam Chongriwa Gyeonghyeop Nonui 구자경 럭키금성회장 베트남 총리와 경협 논의 [Lucky-Goldstar Chairman Koo Ja-Kyung Discussed Economic Cooperation 
with the Vietnamese Prime Minister]. Kyunghyang Shinmun, Feb 13.

[22] Hwang, J. (2009) Lee Embarks on Southeast Asia Trip. Korean Herald, Oct 21. 